\title{
Effect of Hydrological Data on Flood Management in Urban Areas
}

\author{
Sumiharni and Lusmeilia Afriani
}

\begin{abstract}
Floods can occur due to rising water levels due to above-normal rainfall, changes in temperature, broken embankments/dams, rapid snowmelt, obstruction of water flow in other places, and putting people at risk of annual disasters due to flooding. The purpose of this study was to obtain a more detailed description of hydrological conditions so that flooding in the Bandar Lampung urban area can be optimally managed or controlled. The method used in flood control research is the analysis of the calculation of the average rainfall in the watershed, and the calculation of the planned discharge. The results of the analysis show that the existing drainage channels that have been carried out for each channel point have dimensions that are not large enough so that they are not sufficient to accommodate water runoff. so that for a 5-year discharge of $28.058 \mathrm{~m} 3 / \mathrm{s}$, the dimensions of the channel are $3 \mathrm{~m}$ wide and $2.6 \mathrm{~m}$ deep and for a 10 -year discharge of $30.609 \mathrm{~m} 3 / \mathrm{s}$, the channel dimensions are $3.1 \mathrm{~m}$ wide and $2.7 \mathrm{~m}$ deep.
\end{abstract}

Keywords - Flooding, Flood Management, Existing Drainage, Re-planning.

\section{INTRODUCTION}

Floods become a routine phenomenon in the rainy season that occurs in various watersheds (DAS) in most parts of Indonesia [1]. Rainfall patterns, which have recently been erratic, have had a major influence on hydrological analysis and planning, especially the study of watersheds and the design of water structures. Watersheds are described as hydrological units that are home to environmentally based activities [2]-[4]. Watershed management relates to changes in institutional arrangements required for collective action situations. This reflects that watershed sustainability is determined by behavior, socioeconomic conditions, and the level of management that is closely related to institutional organization [5], [6].

Many studies have investigated the impact of human activities on regimes and capacity regulation on one environmental factor [7]. The main cause of the flooding is land use change. The lack of land as a water catchment area has now turned into a residential area and shopping center buildings [8]. Calculation and planning of water structures such as drainage channels, dams, bridges, and other hydraulic structures require rainfall data as the main part of primary data analysis. Watershed management which is part of regional development in Indonesia actually faces various problems such as the lack of integration between sectors, agencies, and regions [5]-[7].
When the rainy season arrives with high rainfall, areas with densely populated settlements and buildings tend to have low infiltration areas, causing the rainwater that falls to become surface runoff water [9]. Surface water flow that exceeds the capacity of the drainage channel causes inundation or flooding [10]. In addition, the drainage channel cannot function properly due to the accumulation of garbage and sediment [11]. Drainage functions to drain, dispose, and or drain abundant water [12]. The drainage system is a water structure that is assembled in order to reduce or dispose of water that cannot be drained into an area or land, so that it can function optimally [13]. Thus, to overcome the problem of flooding, the drainage system must be good.

In urban areas, local inundation occurs during the rainy season, such as on Jl. Kartini Kec. Central Coral Cape. Seeing this background, it is better to do a re-planning for adequate drainage channels so as to reduce the potential for flooding in the area. This research has an urgency for local government policies in terms of flood control in urban areas. While floods that often occur are caused by several factors, while the main factor is human activity. After evaluating the hirological data, it will be known the exact frequency distribution pattern in the watershed around the city of Bandar Lampung.

\section{METHOD}

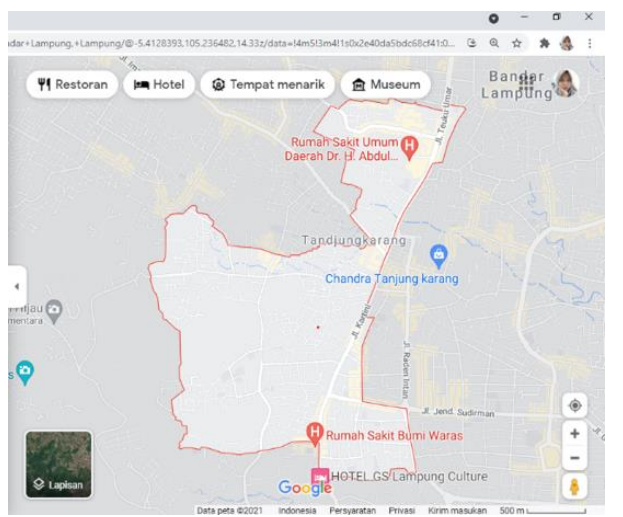

Fig. 1. Map of the location of Tanjung Karang Tengah District.

Location on Jl. Kartini No.21, Durian Payung, Kec. Tj. Karang Pusat, Bandar Lampung City and in front of Horison Hotel Bandar Lampung Identify strategies for Water and Land Resources Management. In accordance with the objectives and limitations of the discussion in this paper, namely emphasizing green open spaces and identification of management techniques and flood control/countermeasures.

Lusmeilia Afriani, Universitas Lampung, Indonesia. (e-mail: afriani_L@eng.unila.ac.id) 
The purpose of this identification is to obtain problems and plans/programs for flood management and mitigation.

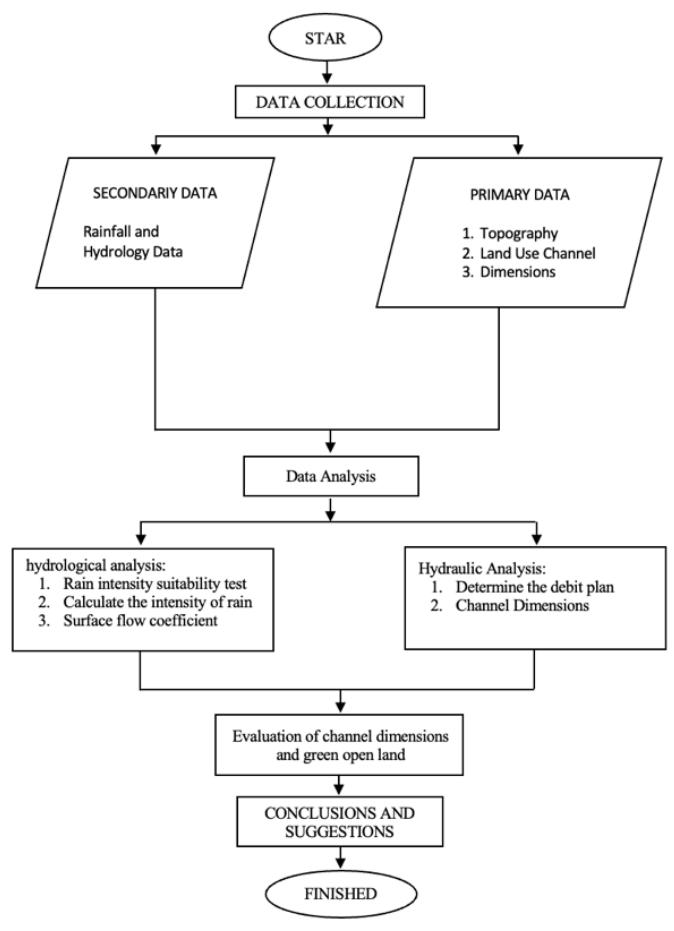

Fig. 2. Research Flowchart.

\section{RESULTS AND DisCUSSION}

A. Rain Intensity Analysis

a) Calculation of mean rain

$$
\bar{p}=\frac{p 1+p 2+p 3+\cdots+p n}{n}
$$

Calculation of average rain in 2012:

$$
\bar{R}=\frac{58+0,8+45+60}{4}=40,950 \mathrm{~mm}
$$

\begin{tabular}{|c|c|c|c|c|c|c|}
\hline \multirow{2}{*}{ No } & \multirow{2}{*}{ Year } & \multicolumn{4}{|c|}{ Station } & \multirow{2}{*}{ Mean } \\
\hline & & PH-001 & PH-003 & PH-004 & PH-005 & \\
\hline 1 & 2012 & 58 & 0,800 & 45 & 60 & 40,950 \\
\hline 2 & 2013 & 152 & 107,2 & 125 & 120 & 126,050 \\
\hline 3 & 2014 & 104 & 66 & 47 & 97 & 78,5 \\
\hline 4 & 2015 & 85 & 40,8 & 62 & 75 & 65,7 \\
\hline 5 & 2016 & 64 & 62 & 64 & 103 & 73,250 \\
\hline 6 & 2017 & 127 & 55 & 58 & 140 & 95 \\
\hline 7 & 2018 & 83 & 105 & 58 & 76 & 80,5 \\
\hline 8 & 2019 & 81 & 215 & 98 & 130 & 131 \\
\hline \multirow[t]{2}{*}{9} & 2020 & 115 & 160 & 104 & 125 & 126,125 \\
\hline & & total & - & - & - & 817,075 \\
\hline
\end{tabular}

TABLE I: ANNUAL RAINFALL

b) Calculation of statistical parameters Calculation of Logarithmic Distribution Average data $(\bar{R})$

$$
\bar{R}=\frac{\sum \mathrm{R}}{\mathrm{n}}=\frac{40,04571}{9}=4,450 \mathrm{~mm}
$$

TABLE II: CALCULATION OF LOGARITHMIC DISTRIBUTION

\begin{tabular}{cccccc}
\hline No & LnR & $\operatorname{Ln}(\mathrm{R}-\overline{\boldsymbol{R}})$ & $\begin{array}{c}\mathrm{Ln}(\mathrm{R}- \\
\overline{\boldsymbol{R}})^{2}\end{array}$ & $\operatorname{Ln}(\mathrm{R}-\overline{\boldsymbol{R}})^{3}$ & $\operatorname{Ln}(\mathrm{R}-\overline{\boldsymbol{R}})^{4}$ \\
\hline 1 & 3,71235 & $-0,73717$ & 0,54342 & $-0,40060$ & 0,29531 \\
2 & 4,18510 & $-0,26442$ & 0,06992 & $-0,01849$ & 0,00489 \\
3 & 4,29388 & $-0,15565$ & 0,02423 & $-0,00377$ & 0,00059 \\
4 & 4,36310 & $-0,08642$ & 0,00747 & $-0,00065$ & 0,00006 \\
5 & 4,38826 & $-0,06127$ & 0,00375 & $-0,00023$ & 0,00001 \\
6 & 4,55388 & 0,10435 & 0,01089 & 0,00114 & 0,00012 \\
7 & 4,83668 & 0,38716 & 0,14989 & 0,05803 & 0,02247 \\
8 & 4,83727 & 0,38775 & 0,15035 & 0,05830 & 0,02261 \\
9 & 4,87520 & 0,42567 & 0,18120 & 0,07713 & 0,03283 \\
Totality & 40,04571 & 0.00000 & 1,14112 & $-0,22913$ & 0,37888 \\
\hline
\end{tabular}

Source: Calculation Results.

Standard Deviation $(\sigma)$

$$
\sigma=\sqrt{\frac{\sum \operatorname{Ln}(\overline{\mathrm{R}}-\llbracket \mathrm{R}) \rrbracket^{2}}{\mathrm{n}-1}}=\sqrt{\frac{1,14112}{9-1}}=0,378
$$

Coefficient of Variation (Cv):

$$
\mathrm{Cv}=\frac{\sigma}{\overline{\mathrm{R}}}=\frac{0,378}{4,450} \quad=0,085
$$

Stiffness Coefficient (Cs):

$$
\mathrm{Cs}=\frac{\mathrm{n} \cdot \ln (\mathrm{R}-\overline{\mathrm{R}})^{3}}{(\mathrm{n}-1)(\mathrm{n}-2) \sigma^{3}}=\frac{9 \cdot(-0,229134)}{(9-1) \cdot(9-2) \cdot 0,378^{3}}=-0,684
$$

Kurtosis Coefficient (Ck):

$$
\mathrm{Ck}=\frac{n^{2} \cdot \ln (R-\bar{R})^{4}}{(n-1)(n-2)(n-3) \sigma^{4}}=\frac{9^{2} \cdot 0,378876}{(9-1) \cdot(9-2) \cdot(9-3) \cdot 0,378^{4}}=4,489
$$

\begin{tabular}{|c|c|c|c|}
\hline \multicolumn{4}{|c|}{ STATISTICS } \\
\hline $\begin{array}{c}\text { Distribution } \\
\text { Type }\end{array}$ & $\begin{array}{c}\text { Distribution } \\
\text { Terms }\end{array}$ & Results & Conclusion \\
\hline \multirow{5}{*}{$\begin{array}{c}\text { Normal } \\
\text { Distribution }\end{array}$} & $\mathrm{Cs}=0$ & & \multirow{5}{*}{ Does not meet } \\
\hline & $C_{v} \approx 3$ & $\mathrm{Cs}=0,027$ & \\
\hline & $(\bar{x} \pm s)=$ & $\mathrm{Ck}=3,145$ & \\
\hline & $68,27 \%$ & $55,55 \%$ & \\
\hline & $\begin{array}{c}(\bar{x} \pm 2 s)= \\
95,44 \%\end{array}$ & $\infty$ & \\
\hline & $\begin{array}{l}C_{s} \\
=C_{v}^{3}+3 C_{v}\end{array}$ & & \multirow{3}{*}{ Does not meet } \\
\hline Normal Log & $C_{k}$ & $\mathrm{Cs}=-0,684$ & \\
\hline Distribution & $\begin{array}{l}=C_{v}^{8}+6 C v^{6} \\
+15 C_{v}^{4} \\
+16 C_{v}^{2}+3\end{array}$ & $\mathrm{Ck}=4,489$ & \\
\hline Gumbel & $\begin{array}{l}\text { Cs } \\
\approx 1,14\end{array}$ & \multirow{2}{*}{$\begin{aligned} \mathrm{Cs} & =0,027 \mathrm{Ck} \\
& =3,145\end{aligned}$} & \multirow{2}{*}{ Does not meet } \\
\hline Distribution & $\mathrm{Ck} \approx 5,4$ & & \\
\hline $\begin{array}{l}\text { Person III } \\
\text { Log } \\
\text { Distribution }\end{array}$ & $\begin{array}{l}\text { Does nor } \\
\text { meet the } \\
\text { requirements } \\
\text { above }\end{array}$ & OK & OK \\
\hline
\end{tabular}

After obtaining the value of the coefficient of curvature and the coefficient of kurtosis, a calculation check is carried out to determine the type of distribution to be used as calculated in Table III.

TABLE III: CONDITIONS FOR THE DISTRIBUTION OF MAXIMUM RAINFALL

Source: Calculation Results.

\section{B. Analysis of Rainfall Intensity Analysis}

After calculating the statistical parameters, distribution selection and distribution tests that have been carried out, the 
planned rainfall calculation uses the Pearson III Log distribution. So that the variables obtained from the calculation are as follows:

Number of data $=9$

Standard Deviation: $\left.\sigma=\sqrt{\frac{1,14112}{9-1}}\right)=0,378$.

Stiffness Coefficient: $\mathrm{Cs}=\frac{9 \cdot(-0,229134)}{(9-1) \cdot(9-2) \cdot 0,378^{3}}=-0,684$.

By interpolating the value of the slope coefficient, the KT value is obtained based on the negative slope coefficient table.

TABLE IV. KT VALUES FOR THE PEARSON III LOG DISTRIBUTION

\begin{tabular}{ccc}
\multicolumn{3}{c}{ (NEGATIVE DESCENT) } \\
\cline { 2 - 3 } Cs & \multicolumn{2}{c}{ When Repeat } \\
\hline$-0,600$ & 0,857 & 10 \\
$\mathbf{- 0 , 6 8 4}$ & $\mathbf{0 , 8 5 7}$ & 1,200 \\
$-0,700$ & 0,857 & $\mathbf{1 , 1 8 6}$ \\
\end{tabular}

Source: Calculation Results.

Based on the obtained KT value, it can be determined the amount of planned rainfall with a certain return period.

TABle V: Calculation of Planned Rainfall by the Pearson III LOG METHOD

\begin{tabular}{ccccc}
\multicolumn{5}{c}{ LOG METHOD } \\
\hline $\mathrm{T}$ (tahun) & $\begin{array}{c}\mathrm{P} \\
(\%)\end{array}$ & $\mathrm{KT}$ & $\mathrm{yT}$ & $\mathrm{P}=\operatorname{arc} \ln \mathrm{y}$ \\
\hline 5 & 80 & 0.857 & 5.035 & 153.6996 \\
10 & 90 & 1.186 & 5.260 & 192.4815
\end{tabular}

Source: Calculation Results.

In calculating the intensity of rainfall, it is necessary to know in advance the time (duration) of the effective rain. According to SNI 03-2453-2002, it can be calculated using the formula:

$$
\mathrm{t}_{\mathrm{e}}=\frac{0.9 R^{0,92}}{60}(\text { time })
$$

An example of a concentration time calculation on a 5year return period.

$$
\begin{gathered}
\mathrm{R}_{5}=153.6996 \mathrm{~mm} \\
\mathrm{t}_{\mathrm{e}}=\frac{0.9(153,6996)^{0,92}}{60}(\text { time })=1,5410 \text { time }
\end{gathered}
$$

Or use the Mononobe method with the following formula:

$$
I=\frac{R_{24}}{24}\left(\frac{24}{t}\right)^{2 / 3}
$$

TABLE VI: RAINFALL INTENSITY

\begin{tabular}{cccc}
\hline $\begin{array}{c}\text { When } \\
\text { Repeat } \\
(\text { Year })\end{array}$ & $\begin{array}{c}\mathrm{R}_{24} \\
(\mathrm{~mm})\end{array}$ & $\begin{array}{c}\text { Rain } \\
\text { Duration } \\
\left(\mathrm{t}_{\mathrm{e}}\right)(\mathrm{time})\end{array}$ & Rain Intensity $(\mathrm{mm} /$ time) \\
\hline $\mathbf{5}$ & $\mathbf{1 5 3 . 6 9 9 6}$ & $\mathbf{1 , 5 4 1 1}$ & $\mathbf{3 9 , 9 3 7 6}$ \\
10 & 192.4815 & 1,8955 & 43,5682 \\
\hline
\end{tabular}

Source: Calculation Results.

\section{Plan Flood Discharge}

Analysis of Planned Flood Discharge the Rational Method is the method most often used to estimate the discharge in a watershed. For an area of less than $50 \mathrm{~km}^{2}$, a rational method can be used to calculate the planned flood discharge for the area. In this case, the magnitude of the discharge is a function of the area of the watershed, the intensity of the rain, the condition of the ground surface which is expressed in the runoff coefficient and the slope of the river [14].

Flood discharge is formulated generically as follows:

$$
\mathrm{Q}=\text { C. I. A }
$$

\begin{tabular}{|c|c|c|c|}
\hline $\begin{array}{c}\text { Conditions } \\
\text { of Flow } \\
\text { District }\end{array}$ & $\begin{array}{l}\text { Land } \\
\text { area } \\
\text { (ha) }\end{array}$ & $\begin{array}{c}\text { Runoff } \\
\text { Coefficient }\end{array}$ & Combination Coefficient \\
\hline Settlement & 334 & 0,4 & 0,2789 \\
\hline Pavement & 101 & 0,95 & 0,2003 \\
\hline Green Area & 58 & 0,4 & 0,0484 \\
\hline Totality & 479 & - & 0,5276 \\
\hline
\end{tabular}

For the calculation of the composite coefficient of the research area as follows:

TABLE VII: RUNOFF COEFFICIENT

The flood discharge is formulated genetically as follows:

$$
\mathrm{Q}=\mathrm{CIA}
$$

For the area in ha, then:

$$
\begin{gathered}
\mathrm{Q}=0,00278 \text {. C.I.A } \\
\mathrm{Q}=0,00278.0,5276.39,9376.479=28,058 \mathrm{~m}^{3} / \mathrm{dtk} \text { (Debit } \\
\text { Kala Ulang 5 tahun) }
\end{gathered}
$$

TABLE VIII: REGIONAL FLOOD DISCHARGE

\begin{tabular}{cccc}
\hline $\begin{array}{c}\text { When } \\
\begin{array}{c}\text { Repeat } \\
\text { (Year) }\end{array}\end{array}$ & $\begin{array}{c}\text { Runoff } \\
\text { Coefficient }\end{array}$ & $\begin{array}{c}\text { Rain } \\
\text { Intensity } \\
(\mathrm{mm} / \mathrm{jam})\end{array}$ & Q $_{\text {teoritis }}\left(\mathrm{m}^{3} /\right.$ detik $)$ \\
\hline 5 & 0,5276 & 39,9376 & 28,058 \\
10 & 0,5276 & 43,5682 & 30,609 \\
\hline
\end{tabular}

\section{Drainage Channel Dimensions}

In calculating the dimensions of the drainage channel, the Manning formula is used. This formula is widely used in open flow and in pipe drainage, with the following formula:

$$
\mathrm{Q}_{\mathrm{T}}=\frac{1}{n} R^{2 / 3} I^{1 / 2} A
$$

Calculation of the Existing Section of Channel Point 1.

Channel top width $(\mathrm{b})=0.55 \mathrm{~m}$.

Wet height of channel $(\mathrm{h})=0.63 \mathrm{~m}$.

Channel base slope $(\mathrm{I})=0.001$.

Manning coefficient $(\mathrm{n})=0.015$ (Concrete)

Channel slope $(\mathrm{m})=0.5917\left(\right.$ angle $\left.60^{\circ}\right)$.

Cross-sectional area:

$$
A=b+(m h) h=0,5813 m^{2}
$$

Wet Circumference:

$$
P=b+2 h\left(1+m^{2}\right)^{0,5}=2,0140 m
$$

Hydraulic spokes:

$$
R=\mathrm{A} / \mathrm{P}=0,2886 \mathrm{~m}
$$


TABLE IX: EXISTING CHANNEL CAPACITY

\begin{tabular}{|c|c|c|c|c|c|c|c|c|c|c|c|}
\hline Titik & $\mathrm{L}(\mathrm{m})$ & $\mathrm{B}(\mathrm{m})$ & $\mathrm{H}(\mathrm{m})$ & $\mathrm{m}$ & $\mathrm{A}\left(\mathrm{m}^{2}\right)$ & $\mathrm{P}(\mathrm{m})$ & $\mathrm{Rm})$ & I & $\mathrm{n}$ & $\mathrm{V}(\mathrm{m} / \mathrm{s})$ & $\mathrm{Qt}\left(\mathrm{m}^{3} / \mathrm{s}\right)$ \\
\hline & 0 & 0.55 & 0.63 & 0.5917 & 0.5813 & 2.0140 & 0.2886 & 0.001 & 0.015 & 0.9207 & 0.5352 \\
\hline & 330 & 1.1 & 0.9 & 0.5917 & 1.4692 & 3.1914 & 0.4603 & 0.001 & 0.015 & 1.2569 & 1.8467 \\
\hline & 740 & 0.95 & 1.2 & 0.5917 & 1.9920 & 3.7386 & 0.5328 & 0.001 & 0.015 & 1.3855 & 2.7601 \\
\hline & 130 & 0.95 & 0.7 & 0.5917 & 0.9549 & 2.5767 & 0.3706 & 0.001 & 0.015 & 1.0877 & 1.0386 \\
\hline
\end{tabular}

Flow Speed:

$\mathrm{V}=\frac{1}{n} \times \mathrm{R}^{2 / 3} \times \mathrm{I}^{1 / 2}=\frac{1}{0,015} \times 0,2886^{2 / 3} \times 0,001^{1 / 2}=0,920772$

Channel Debit:

$$
\mathrm{Q}_{\mathrm{T}}=\mathrm{V} \times \mathrm{A}=0,5352 \mathrm{~m}^{3} / \text { detik }
$$

High care (W):

$$
\mathrm{W}=\sqrt{0,5 h}=0,5612 \mathrm{~m}
$$

Furthermore, the results of the calculation of the channel capacity can be seen in Table IX.

\section{E. Comparison of Channel Capacity with Flood Discharge}

Comparison of the capacity of the existing canal with the planned flood discharge aims to find out which channels are unable to accommodate the calculated Q plans.

TABLE X: COMPARISON OF CHANNEL CAPACITY WITH FLOOD

\begin{tabular}{ccccc}
\multicolumn{5}{c}{ DisCHARGE } \\
\hline Point & $\mathrm{Qt}\left(\mathrm{m}^{3} / \mathrm{dtk}\right)$ & $\mathrm{Qr}_{5}\left(\mathrm{~m}^{3} / \mathrm{dtk}\right)$ & $\mathrm{Qr}_{10}\left(\mathrm{~m}^{3} / \mathrm{dtk}\right)$ & Status \\
\hline 1 & 0.5352 & 28,058 & 30,609 & overflow \\
2 & 1.8467 & 28,058 & 30,609 & overflow \\
3 & 2.7601 & 28,058 & 30,609 & overflow \\
4 & 1.0386 & 28,058 & 30,609 & overflow \\
\hline
\end{tabular}

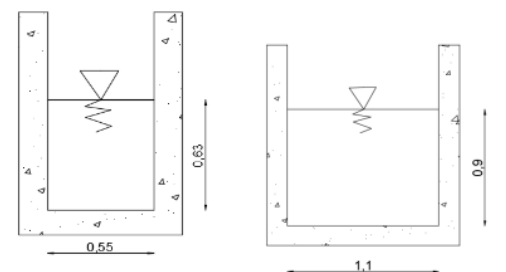

Fig. 3. Existing Sections of Point 1 and Point 2 Saluran Channels.
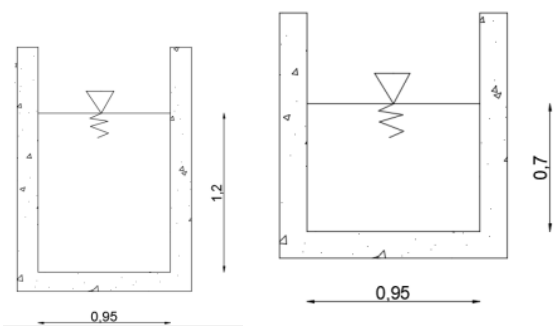

Fig. 4. Existing Sections of Point 3 and Point 4 Saluran Channels.

\section{F. Debit Calculation with a Return Period of 5 Years}

Planned:

Theoretical discharge $(\mathrm{Qt})=28.058 \mathrm{~m}^{3} / \mathrm{s}$

Channel top width $(\mathrm{b})=3 \mathrm{~m}$.

Wet height of the channel $(\mathrm{h})=0.86665 \mathrm{~b}=2.6 \mathrm{~m}$.

Channel base slope $(\mathrm{I})=0.001$.

Manning coefficient $(\mathrm{n})=0.015$ (Concrete).

Slope $(\mathrm{m})=0.5917($ angle $60 \mathrm{o})$.
Cross-sectional area:

$$
A=b+(m h) h=11,7873 m^{2}
$$

Wet Circumference:

$$
P=b+2 h\left(1+m^{2}\right)^{0,5}=9,036 m
$$

Hydraulic spokes:

$$
R=\mathrm{A} / \mathrm{P}=1,30448 \mathrm{~m}
$$

Flow Speed:

$\mathrm{V}=\frac{1}{n} \times \mathrm{R}^{2 / 3} \times \mathrm{I}^{1 / 2=} \frac{1}{0,015} \times 1,30448^{2 / 3} \times 0,001^{1 / 2}=2,5169 \mathrm{~m} / \mathrm{s}$

Channel Debit:

$$
\mathrm{Q}_{\mathrm{T}}=\mathrm{V} \times \mathrm{A}=29,6675 \mathrm{~m}^{3} / \mathrm{s}
$$

High care (W):

$$
\mathrm{W}=\sqrt{0,5 h}=1,140 \mathrm{~m}
$$

Check the debit that occurs for the 5 year anniversary:

$$
\begin{aligned}
& \mathrm{Q}_{\mathrm{t}}=28,058 \mathrm{~m}^{3} / \mathrm{dtk}, \mathrm{Q}_{\text {rencana }}=29,6675 \mathrm{~m}^{3} / \mathrm{s} \\
& \mathbf{Q}_{\mathrm{t}} \leq \mathbf{Q}_{\text {rencana }} \ldots . . . \text { OK!!!! }
\end{aligned}
$$

\section{G. Debit Calculation with a Return Period of 10 Years}

Planned:

Theoretical discharge $(\mathrm{Qt})=30.609 \mathrm{~m}^{3} / \mathrm{s}$.

Channel top width $(\mathrm{b})=3.1 \mathrm{~m}$.

Wet height of channel $(\mathrm{h})=0.86665 \mathrm{~b}=2.7 \mathrm{~m}$.

Channel base slope $(\mathrm{I})=0.001$.

Manning coefficient $(\mathrm{n})=0.015$ (Concrete).

Slope $(\mathrm{m})=0.5917\left(\right.$ angle $\left.60^{\circ}\right)$.

Cross-sectional area:

$$
\text { A } \quad=b+(m h) h=12,5862 m^{2}
$$

Wet Circumference:

$$
P=b+2 h\left(1+m^{2}\right)^{0,5}=9,3372 m
$$

Hydraulic spokes:

$$
R=\mathrm{A} / \mathrm{P}=1,3479 \mathrm{~m}
$$

Flow Speed:

$\mathrm{V}=\frac{1}{n} \times \mathrm{R}^{2 / 3} \times \mathrm{I}^{1 / 2=} \frac{1}{0,015} \times 1,3479^{2 / 3} \times 0,001^{1 / 2}=2,57245$ 
Channel Debit:

$$
\mathrm{Q}_{\mathrm{T}}=\mathrm{V} \times \mathrm{A}=32,3773 \mathrm{~m}^{3} / \mathrm{s}
$$

\section{Channel Debit (W):}

$\mathrm{W}=\sqrt{0,5 h}=1,160 \mathrm{~m}$

Check the debit that occurs for the 5 year anniversary:

$$
\begin{aligned}
& \mathrm{Q}_{\mathrm{t}}=30,609 \mathrm{~m}^{3} / \mathrm{s}, \mathrm{Q}_{\text {rencana }}=32,3773 \mathrm{~m}^{3} / \mathrm{s} \\
& Q_{\mathrm{t}} \leq Q_{\text {rencana }} \ldots . . . \text { OK!!!! }
\end{aligned}
$$

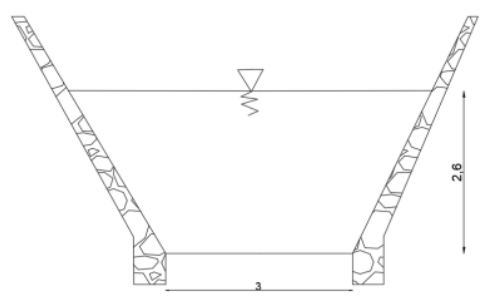

Fig. 5. Planned Section $\mathrm{Q}_{5}$.

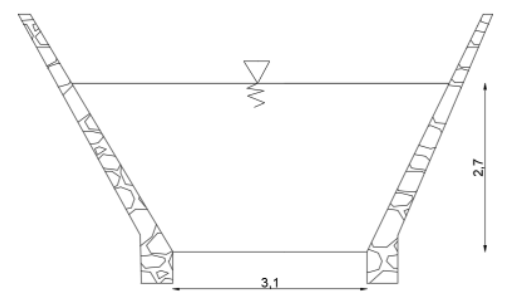

Fig. 6. Planned Section $\mathrm{Q}_{10}$.

\section{H. Conclusion}

From the results of research that has been carried out, the following conclusions are obtained:

From the results of data obtained from 2009 to 2015 data, it shows that green open space in 2013 was 58 ha from an area of 479 ha in the Tanjung Karang Pusat sub-district. The planned flood discharge for the 5-year return period is $28.058 \mathrm{~m}^{3} / \mathrm{s}$ and for the 10-year return period is $30.609 \mathrm{~m}^{3} / \mathrm{s}$. While the existing channel discharge at point 1 is $0.5352 \mathrm{~m}^{3} / \mathrm{s}$, point $2=1.8467 \mathrm{~m}^{3} / \mathrm{s}$, point $3=2.7601 \mathrm{~m}^{3} / \mathrm{s}$, and point $4=1.0386 \mathrm{~m}^{3} / \mathrm{s}$ causing flooding. The results of the design of drainage channel dimensions that meet the planned flood discharge for the 5-year return period are channel width $(\mathrm{b})=3 \mathrm{~m}$, depth $(\mathrm{h})=2.6 \mathrm{~m}$, with $\mathrm{Qr}=29.6675 \mathrm{~m}^{3} / \mathrm{sec}$. And for the 10-year return period, the channel width (b) = $3.1 \mathrm{~m}$, depth $(\mathrm{h})=2.7 \mathrm{~m}$, with $\mathrm{Qr}=32.3773 \mathrm{~m}^{3} / \mathrm{sec}$.

\section{CONCLUSION}

A conclusion section is not required. Although a conclusion may review the main points of the paper, do not replicate the abstract as the conclusion. A conclusion might elaborate on the importance of the work or suggest applications and extensions. doi: https://doi.org/10.33506/rb.v7i1.1228

[2] M. Common and S. Stagl, Ecological Economic: An Introduction. Cambridge University Press, New York, 2015.

[3] G. T. Miller and S. E. Spoolman. Living in the Environment: Concepts, Connections and Solutions. Seventeenth edition., Brooks/Cole Belmont, CA (USA), 2015.

[4] V. Ratna Reddy, Y. S. Saharawat, and B. George. Watershed management in South Asia: A synoptic review. J. Hydrol., 551: 4-13, Aug. 2017, doi: 10.1016/j.jhydrol.2017.05.043.

[5] S. Chowdhury, M. A. J. Mazumder, O. Al-Attas, and T. Husain. Heavy metals in drinking water: Occurrences, implications, and future needs in developing countries. Sci. Total Environ., 569-570: 476-488, Nov. 2016, doi: 10.1016/j.scitotenv.2016.06.166.

[6] S. Mtibaa, N. Hotta, and M. Irie. Analysis of the efficacy and costeffectiveness of best management practices for controlling sediment yield: A case study of the Joumine watershed, Tunisia'. Sci. Total Environ., 616-617:1-16, Mar. 2018. doi: 10.1016/j.scitotenv.2017.10.290.

[7] A. S. Pambudi. WatershedManagement in Indonesia: A Regulation, Institution, and Policy Review. Indones. J. Dev. Plan., III(2):185-202, 2019

[8] I. Kurniati, I. G. Sugiyanta, and R. K. S. Utami. Deskripsi Lokasi Banjir Di Kecamatan Tanjung Karang Pusat Bandar Lampung 20112013. JPG J. Penelit. Geogr., 3(4), Art. no. 4, Aug. 2015, Accessed: Oct. 18, 2021. [Online]. Available http://jurnal.fkip.unila.ac.id/index.php/JPG/article/view/9716.

[9] T. A. Larasaty, M. C. Nugraha, and E. Hartati. Identifikasi Penentuan Skala Prioritas Penanganan Genangan Atau Banjir Di Kecamatan Karawang Barat. J. Serambi Eng., 5(4), Oct. 2020, doi $10.32672 /$ jse.v5i4.2318.

[10] K. Brata and Nelistya. Lubang Resapan dan Biopori. Penebar Swadaya: Depok, 2008.

[11] V. W. Zahra, B. Sujatmoko, and A. Hendri. Penyusunan Skala Prioritas Saluran Drainase Di Tiga Kecamatan. J. Online Mhs. JOM Bid. Tek. Dan Sains, 5(1), Art. no. 1, Oct. 2017.

[12] Suripin, Sistem Drainase Untuk Perkotaan yang Berkelanjutan. Yogyakarta: Andi, 2004.

[13] B. Sujatmoko. Aplikasi Sistem Informasi Geografis Dalam Mengatasi Banjir Pada Sistem Drainase Di Pekanbaru, Universitas Riau, 2016.

[14] J. Loebis. Banjir Rencana Untuk Bangunan Air. Jakarta: Departemen Pekerjaan Umum, 1992.

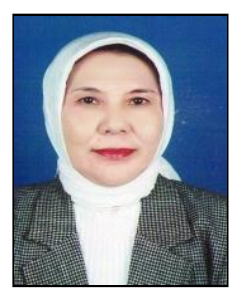

Sumiharni was born on June 6, 1957 in Tanjungkarang, Bandar Lampung Indonesia. She completed his undergraduate program at Sang Bumi Ruwa Jurai University in 1997 in the Civil Engineering section. Sumiharni obtained his Master's degree in 1999 at Gajah Mada University (UGN) in the field of Water Resources Engineering. She is a lecturer at the Faculty of Engineering, University of Lampung. Sumiharni's main field is Civil Hydro.

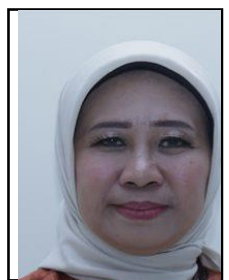

In 1992 Lusmeilia Afriani earned an Ir degree at the Sepuluh Nopember Institute of Technology, a D.E.A at the University of Nantes (2000), and a Dr at the University of De Caen (2004). She is a lecturer at the Faculty of Engineering, University of Lampung. His main field is Geotechnical.

\section{REFERENCES}

[1] A. Andriawan. Kajian Hidrologi Pada Sistem Pengendalian Banjir. Ranc. Bangun, 2021;7(1):35-41. 